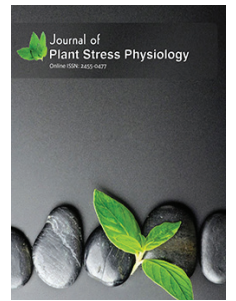

ISSN: $2455^{-0} 0477$
Received: 23-01-2020 Accepted: 26-03-2020 Published: 04-04-2020

*Corresponding Author: Professor Dr. G H M Sagor E-mail: sagorgpb@gmail.com

\section{Screening and biochemical characterization of wheat cultivars resistance to Magnaportbe oryzae pv Triticum (MoT)}

\author{
Chandra Shekhar Biswas', Afsana Hannan', Abul Monsur², G. H. M. Sagor ${ }^{1 *}$ \\ 'Plant Molecular Genetics Laboratory, Department of Genetics and Plant Breeding, Bangladesh Agricultural \\ University, Mymensingh, Bangladesh, ${ }^{2}$ Plant Pathology Division, Bangladesh Rice Research Institute (BRRI), \\ Gazipur, Bangladesh
}

\begin{abstract}
Global food security is seriously threatened due to increased frequency and occurrence of fungal diseases. One example is wheat blast caused by Magnaporthe oryzae is a fungal diseases of rice, wheat, and other grasses, that can destroy the whole food production to sustain millions of people. Wheat blast was first detected in february 2016 with a serious outbreak in Asia. Assessment of the available germplasms to stress tolerant/resistant is one of the best options for developing stress tolerant crop varieties. In this study, a total of sixteen wheat cultivars were collected and test their disease severity to blast pathogen Magnaporthe oryzae pv. Triticum (MoT). Among the varieties, BARI Gom 33 exhibited partially resistance against blast pathogen, whereas all other genotypes become susceptible to MoT. Different yield and yield contributing characters of both resistant and susceptible cultivars were also evaluated and found no significant differences among them. To understand the underlying mechanism of resistance in BARI Gom 33, antioxidant enzyme activity, concentration of reactive oxygen species and cellular damage after fungal infection were also evaluated and found that activities of ascorbate peroxidase (APX), catalase (CAT) and peroxidase (POD) were higher in BARI Gom 33 than BARI Gom 25 and BARI Gom 31. The hydrogen peroxide $\left(\mathrm{H}_{2} \mathrm{O}_{2}\right)$ and malondealdehyde (MDA) content in BARI Gom 33 was low compare to BARI Gom 25 and BARI Gom 31, which may due to greater increase of the APX. CAT and POD in resistant genotypes. Thus, it may suggest that a more efficient antioxidative defense system in BARI Gom 33 during the infection process of M. oryzae restricts the cell damage caused by the fungus. The identified genotypes can either be used directly in the blast prone area or as a source of resistance to further development of blast resistance high yielding wheat variety.
\end{abstract}

KEYWORDS: Wheat, Magnaporthe oryzae pv. triticum, resistance, antioxidant, oxidative stress

\section{INTRODUCTION}

Wheat, the second major staple food source after rice has a crucial role to play for ensuring global food security. It is one of the first tamed crops by human among the grains. In developing countries, wheat is the second source of calories and first sources of protein in the diets of consumers [1]. Around 37.2 million hectares area of southern Asia are under wheat cultivation producing 98.7 million tons of wheat [2]. At present, hexaploid bread wheat accounted for $95 \%$ of the wheat grown throughout the world, following tetraploid durum wheat of about remaining 5\% [3]. Global climate change along with worldwide financial crisis and depletion of natural resourses cause serious threat to the living standard of millions of poor people. It is projected that wheat demand increased to $60 \%$ by 2050 in the developing world [4]. At the same time, several biotic and abiotic stresses constraints the widespread cultivation of wheat. Wheat blast caused by the ascomycetous fungus Magnaporthe oryzae (Triticum pathotype - MoT) [5] is currently the most devastating wheat disease limiting wheat production. Wheat blast is new to Asia, known to cause significant crop losses in some South American countries with warm and humid condition. The disease was first observed in the state of Paraná, Brazil, in 1985 [6]. Wheat blast emerged for the first time in 2016 in several southwestern and southern districts of Bangladesh viz., Pabna, Kushtia, Meherpur, Chuadanga, Jhenaidah, Jessore, Barisal, and Bhola. Almost 3.5\% of total wheat coverage (15000 ha) in Bangladesh was affected by the wheat blast that dwindled total wheat production by $15 \%[5,7]$. Comparative genome analyses revealed that the fungal isolates appeared in Bangladesh was clonal and closely related to highly aggressive MoT isolates from South America $[5,7,8]$. 
Wheat blast is mainly a disease of spike, however, can occur on all aerial plant parts. Severity of the disease greatly depends upon weather conditions, cultivars, and plant organs infected $[9,10]$. Although exact weather conditions required for a field epidemic are not clear, most severe blast outbreaks have coincided with wet years; warm temperatures and high humidity [10]. Whereas, disease management become challenging due to limited knowledge on the factors responsible for wheat blast epidemics However, wheat blast fungus has physiologically and genetically complex character, with a range of aggressiveness and pathotypes. Most of the wheat cultivars are susceptible to wheat blast in Bangladesh [5]. Some studies showed the presence of partially tolerance but the mechanisms is totally unknown [11,12]. Upon any kind of environmental stress condition, wheat plants are being accounted by oxidative damage through accumulation of reactive oxygen species (ROS) inside the cells inhibiting both growth and grain yield [13]. Over-accumulation of ROS affects cellular redox homeostasis and causes oxidative stress $[14,15]$ and plants tend to protect the damage of cell via activating antioxidant mechanism [13]. The antioxidant enzymes comprise of several enzymes such as ascorbate peroxidase (APX), catalase (CAT), guaicol peroxidase (POD), superoxide dismutase (SOD) etc. In wheat, oxidative stress induced by different biotic and abiotic stresses, cause an alteration in the activity of SOD, APX, CAT, $\mathrm{POD}$ and in the ROS concentration are reported both in field and laboratory conditions [16, 17, 18, 19, 20]. Tolerant genotypes generally consist of higher antioxidant activity causing less damage to the cell, which is solely depends on genetic potentiality of cultivars $[13,21]$. Although, involvement of antioxidant systems in pathogen infection have been well documented [22, 23]. Only few studies investigated the relationship between change in antioxidant mechanism to host resistance. There is no report/ work in terms of the tolerance of commercially cultivated wheat genotypes and their tolerance mechanism in Bangladesh. Therefore, this study was aimed to find out blast resistant wheat varieties/cultivars among the old and newly released varieties in Bangladesh and also to measure antioxidant enzymatic activity, ROS accumulation and cell membrane damage (MDA), to know the genetic potential of tolerant and susceptible cultivars.

\section{MATERIALS AND METHODS}

\section{Plant Materials and Growth Condition}

Sixteen varieties/cultivars collected from Bangladesh Agricultural Research Institute (BARI) namely Kheri, Kanchan, Sourav, Gourav, Shatabdi, Sufi, BARI Gom 25, BARI Gom 26, BARI Gom 27, BARI Gom 28, BARI Gom 29, BARI Gom 30, BARI Gom 31, BARI Gom 32, BARI Gom 33 and BROUCK 100 were used for this study. Seeds were surface sterilized and sown on small pots containing soil. Twenty one days old seedlings were used for fungal inoculation. At the same time seeds were also sown in the experimental field laboratory under natural condition to evaluate different yield and yield contributing characters.

\section{Inocula Preparation, Inoculation and Evaluation}

Wheat blast isolates were cultured on readymade oatmeal agar at $26^{\circ} \mathrm{C}$ for 17 days. The surface of culture media was then gently rubbed with a sterile paint brush to remove aerial mycelia and then exposed for 3 days to fluorescent light at $26^{\circ} \mathrm{C}$ to induce sporulation. Conidia from sporulated culture media were scraped and suspended in water containing Tween $20(0.01 \%)$, then filtered and adjusted the concentration of conidia to $1 \times 10^{5} \mu \mathrm{L}$ water. The conidial suspension was sprayed on 21 days old wheat seedlings, incubated at $25^{\circ} \mathrm{C}$ temperature in a humid chamber for 24 hrs. After incubation, seedlings tray were transferred to a temperature controlled plant growth room at $28 \pm 1^{\circ} \mathrm{C}$. Disease score were measured by following Standard Evaluation System (SES, IRRI) [24] after seven days of inoculation.

\section{Antioxidant Enzyme Activity Assay}

Activities of catalase (CAT) (EC 1.11.1.6) [25], Guaiacol peroxidase (POD) (EC 1.11.1.6) [26], and Ascorbate peroxidase (APX) (EC 1.10.3.3) [26] were measured in inoculated plants. Fifty milligrams of fresh plant sample were collected and homogenized with $3 \mathrm{ml}$ of $50 \mathrm{mM}$ potassium phosphate buffer $\left(\mathrm{p}^{\mathrm{H}} 8.0\right)$ in a mortar and pestle. The homogenate was centrifuged at $12,000 \mathrm{rpm}$ for $10 \mathrm{~min}$. In all stages, $4^{\circ} \mathrm{C}$ temperature was maintained. The clear supernatant was used for assaying CAT, POD, APX activity. To measure CAT activity $0.1 \mathrm{~mL}$ of enzyme extract was added to a $0.7 \mathrm{~mL}$ of $50 \mathrm{mM}$ potassium phosphate buffer (pH 8.0), $0.1 \mathrm{ml}$ of EDTA and $0.1 \mathrm{ml}$ of $\mathrm{H}_{2} \mathrm{O}_{2}$ mixture and changes in absorbance were recorded immediately at $240 \mathrm{~nm}$ at 30 seconds interval for two minutes. POD activity was measured by adding $0.1 \mathrm{ml}$ of enzyme extract to a mixture of $0.6 \mathrm{ml}$ of $50 \mathrm{mM}$ potassium phosphate buffer ( $\mathrm{pH} \mathrm{8.0),} 0.1 \mathrm{ml}$ of EDTA, $0.1 \mathrm{ml}$ of $\mathrm{H}_{2} \mathrm{O}_{2}$ and $0.1 \mathrm{ml}$ of guaiacol, and changes in absorbance were recorded immediately at $470 \mathrm{~nm}$ at 30 seconds interval for two minutes. $0.1 \mathrm{~mL}$ of enzyme extract was added to $0.6 \mathrm{ml}$ of $50 \mathrm{mM}$ potassium phosphate buffer $\left(\mathrm{p}^{\mathrm{H}} 8.0\right), 0.1 \mathrm{ml}$ of EDTA, $0.1 \mathrm{ml}$ of $\mathrm{H}_{2} \mathrm{O}_{2}$ and $0.1 \mathrm{ml}$ of ascorbate mixture and changes in absorbance were recorded immediately at $290 \mathrm{~nm}$ at 30 seconds interval for two minutes to measure APX activity.

\section{Determination of Hydrogen Peroxide $\left(\mathrm{H}_{2} \mathrm{O}_{2}\right)$ and Malondialdehyde (MDA) Activity}

Malondialdehyde (MDA) and Hydrogen peroxide $\left(\mathrm{H}_{2} \mathrm{O}_{2}\right)$ content were measured according to the protocol by [27, 28]. Briefly, $0.1 \mathrm{~g}$ leaf tissue (with similar age, and young expanded leaf) was ground into powder with liquid nitrogen, and then the powder was put into a tube containing $1 \mathrm{ml} 0.1 \%(\mathrm{w} / \mathrm{v})$ TCA and mixed by inverting the tube to homogenize the leaf tissue. Homogenized samples were centrifuged at 10,000 rpm for $10 \mathrm{~min}$, and then the supernatants were transferred to a new tube. After centrifugation, the supernatants were kept in dark for $\mathrm{l} h$ after mixing with phosphate buffer $(10 \mathrm{mM}, \mathrm{pH} 7.0)$ and potassium iodide $(\mathrm{l} \mathrm{M}$ ) (in the ratio of $0.5 \mathrm{ml} 0.5 \mathrm{ml} \mathrm{l} \mathrm{ml}$ ). Absorbance of the resulting solution was recorded at $390 \mathrm{~nm}$. For MDA content measurement, $4 \mathrm{ml}$ of $20 \%$ TCA containing $0.5 \%$ TBA was added to the supernatant and mixed well. The mixture was boiled at $95^{\circ} \mathrm{C}$ for $15 \mathrm{~min}$ and quickly cooled on ice (TBA can interact with MDA and resulted into red compound in acidic buffer, so the content of MDA can be calculated by measuring the density of the resulting red compound with 
spectrophotometer at $532 \mathrm{~nm}$. All the steps were performed at $4{ }^{\circ} \mathrm{C}$ except absorbance measurement.

\section{Statistical Analysis}

All experiments were performed with at least three biological samples and three time repetition unless mentioned. Data analysis was performed using the Statistical tools (Student's t-test) of Microsoft Excel software.

\section{RESULTS}

\section{Assessment of Wheat Genotypes for Blast Tolerance}

A number of sixteen wheat varieties/cultivars were grown in plastic tray filled up with soil (Fig. 1b) at plant growth room, Department of Genetics and Plant Breeding. The collected blast pathogen was grown on oat agar media (Fig. la) and conidial suspension were sprayed on twenty one days old seedlings and scoring were done seven days after inoculation (Fig. 1 c,d). On the basis of the system score 0 indicated $0 \%$ leaf area infection and score 9 denoted more than $65 \%$ leaf area infection. In score 8 extensive leaf curling and browning of upper and middle leaves were prevalent. Plants were generally stunted and many plants were died. On the other hand in score 3 several lesions were randomly scattered within the plot and the lesions number were ranged from 1 to 4 . In case of control plant, no lesions were developed. Among the cultivars tested, BARI Gom 33 scored as three (3); BARI Gom 20, BARI Gom 25 and BARI Gom 29 scored as eight (8); and others were scored as seven (7). (Table 1)

\section{Evaluation of Yield and its Attributing Traits in Tolerant and Susceptible Cultivars}

The selected moderately tolerant variety BARI Gom 33 along with BARI Gom 25 (Score 8) and BARI Gom 31 (score 7) were also grown in the experimental field laboratory of Genetics \& Plant Breeding department under natural growth condition

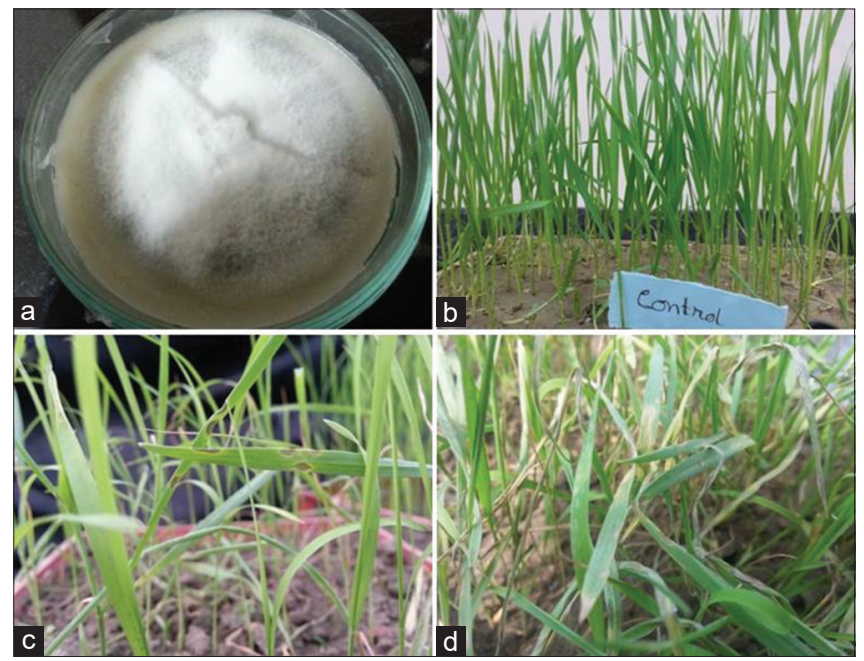

Figure 1 Assessment of wheat genotypes tolerance to Magnaporthe oryzae pv Triticum. a) Inocula preparation; b) Growing of plant in plastic tray; c, d) Plant after inoculation and scoring stage for evaluation of normal yield and yield contributing traits such as days to $50 \%$ flowering, spikelets per spike, grains per spike, 100-grain weight. There is no marked difference among the genotypes in terms of tested traits under normal growth condition. The maximum value were obtained for spikelets number per spike in BARI Gom 25, grain number per spike in BARI Gom 31, 100-grain weight in BARI Gom 33 and yield per plant in BARI Gom 33 and minimum yield per plant were obtained in BARI Gom 31 (Table 2). Other some varieties were also tested for those characters (data not shown), but their performance was also not better than BARI Gom 33, BARI Gom 25.

\section{$\mathrm{H}_{2} \mathrm{O}_{2}$ (Hydrogen Peroxide) and MDA (Malondialdehyde) Content; Antioxidant Enzyme Activity}

Upon inoculation of blast pathogen the content of $\mathrm{H}_{2} \mathrm{O}_{2}$, MDA were tested in both tolerant and susceptible genotypes. It was found that accumulation of both compound were less in BARI Gom 33, high in BARI Gom 25 and BARI Gom 31 after seven days of inoculation (Figure 2a). The different antioxidant enzyme (APX, CAT, POD) involved in the detoxification of oxidative stress were also estimated and in all cases the activity is high in tolerant genotypes BARI Gom 33 as compared to susceptible variety BARI Gom 25 and BARI Gom 31 (Figure 2b).

\section{DISCUSSION}

A number of total sixteen wheat varieties including some recent cultivars were collected from BARI and undergoes for their disease resistance at seedling stage and also phenotypic evaluation for yield and yield contributing characters were performed under normal field condition. The evaluations of tolerance among the collected cultivars were measured by the Standard Evaluation System (SES) [24]. Upon inoculation of $M$. oryzae pv triticum, plant showed stunted growth and developed lesions on the leaf. Among the cultivars, BARI Gom 20 (Gourav), BARI Gom 25 and BARI Gom 29 were found more susceptible to MoT as it scored 8 (Table 1). According to SES, in score 7 , tips of most upper leaves were curling, upper and middle leaves were brown and most of the leaves were going to be dead. Kheri, Kanchan, BARI Gom 19 (Sourav), BARI Gom

Table 1: Assessment of wheat cultivars in terms of leaf injury score after inoculating wheat blast pathogen

\begin{tabular}{lccc}
\hline Name of cultivar/variety & $\begin{array}{c}\text { Disease score } \\
\text { Name of cultivar/ Disease score } \\
\text { variety }\end{array}$ \\
\hline Kheri & 7 & BARI Gom 27 & 7 \\
Kanchan & 7 & BARI Gom 28 & 7 \\
BARI Gom 19 (Sourav) & 7 & BARI Gom 29 & 8 \\
BARI Gom 20 (Gourav) & 8 & $\begin{array}{c}\text { BARI Gom 30 } \\
\text { BARI Gom 31 }\end{array}$ & 7 \\
BARI Gom 21 (Shatabdi) & 7 & $\begin{array}{c}\text { (BAW-1182) } \\
\text { BARI Gom 32 }\end{array}$ & 7 \\
BARI Gom 22 (Sufi) & 7 & $\begin{array}{c}\text { (BAW-1202) } \\
\text { BARI Gom 33 } \\
\text { (BAW-1260) }\end{array}$ & 3 \\
BARI Gom 25 & 8 & $\begin{array}{c}\text { BROUCK-100 } \\
\text { (BAW-1300) }\end{array}$ \\
BARI Gom 26 & 7 & & 7 \\
\hline
\end{tabular}


Table 2: Evaluation of tolerant and susceptible cultivars in terms of yield and its contributing traits

\begin{tabular}{lccccc}
\hline Variety / Cultivar & Days to 50 \% flowering & Spikelets/spike & Grains/spike & 100-grain weight (g) & Yield/plant (g) \\
\hline BARI Gom 33 (BAW-1260) & 69 & 19 & 51 & 3.5 & 9.5 \\
BARI Gom 31 (BAW-1120) & 70 & 18 & 59 & 3.0 & 8.5 \\
BARI Gom 25 & 67 & 21 & 47 & 3.3 \\
\hline
\end{tabular}

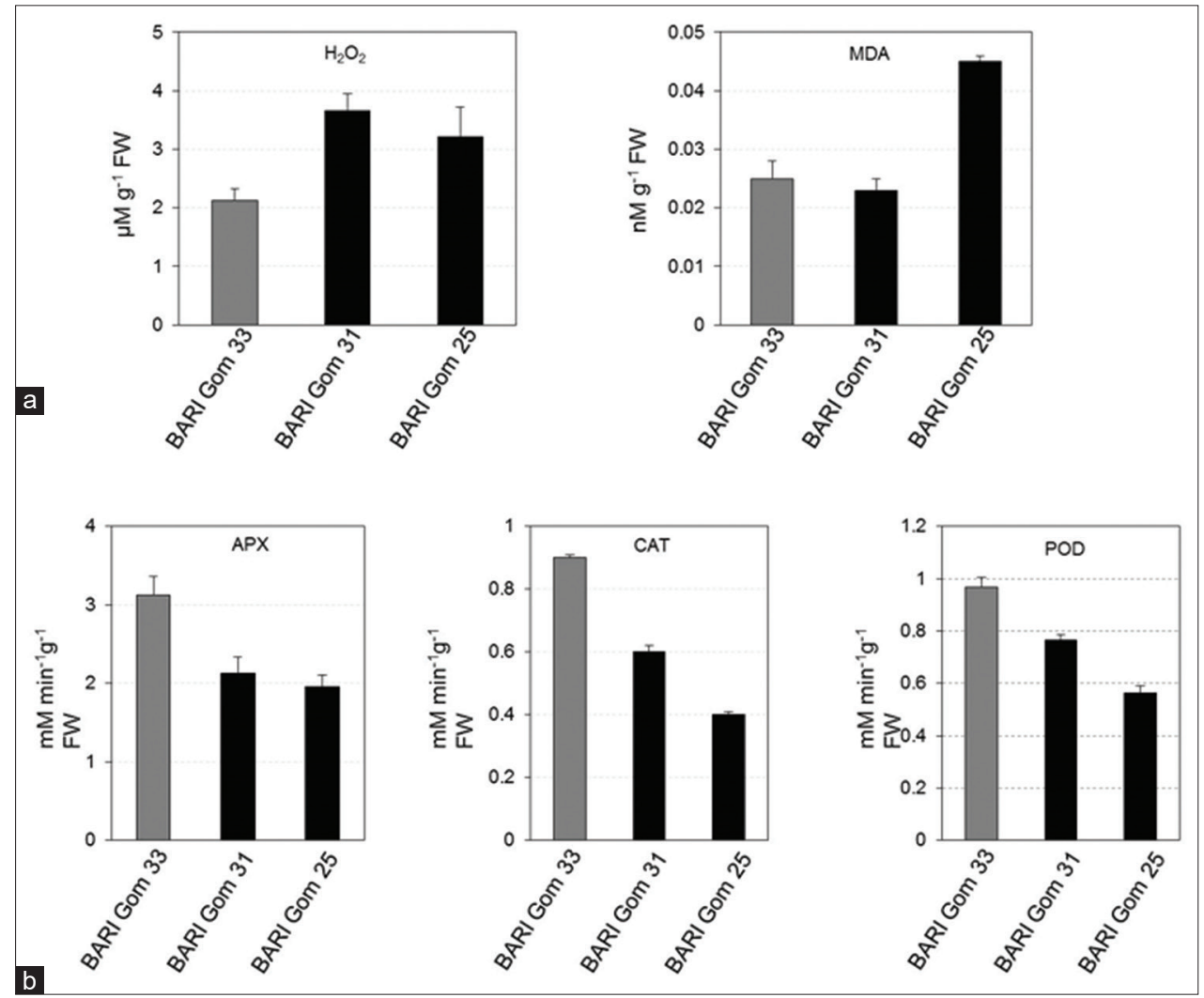

Figure 2 Antioxidant activity in response to disease infection a) MDA and $\mathrm{H}_{2} \mathrm{O}_{2}$ content b) APX, CAT and POD activity in moderately tolerant and susceptible genotype under disease condition

21 (Shatabdi), BARI Gom 22 (Sufi), BARI Gom 26, BARI Gom 27, BARI Gom 28, BARI Gom 30, BARI Gom 31 (BAW-1182), BARI Gom 32 (BAW-1202), BROUCK 100 (BAW-1300) were found susceptible to MoT as it scored 7 [24]. On the other hand in score 3 several lesions were randomly scattered within the plot and the lesions number were ranged from 1 to 4 . Only BARI Gom 33 showed resistance to MoT as it scored 3 [24], having similarity to the finding of other researcher [29]. The partially tolerant BARI Gom 33 showed similar rather better performance in terms of yield and yield contributing traits under natural field condition which is also similar to the results of [29] indicating their greater performance under normal and stressed condition.

The identified tolerant and susceptible varieties were biochemically analyzed to understand the response of antioxidant system in tolerance mechanism. Biotic stress generally leads to an overproduction of reactive oxygen species (ROS) like $\mathrm{H}_{2} \mathrm{O}_{2}$ and MDA which are responsible for oxidative stress. During pathogenic infection, ROS accumulation is important defensive mechanism [30] which mainly happened due to imbalance between their production and host defense responses that cause damage to the host. Plant cell activate a number of enzymatic and non-enzymatic systems to cope the situation and maintain constant level in cells [31]. In the present study, higher accumulation of hydrogen peroxide $\left(\mathrm{H}_{2} \mathrm{O}_{2}\right)$ during infection by MoT contributed to higher concentration of malondealdehyde (MDA) in BARI Gom 31 and BARI Gom 25 as compared to BARI Gom 33. In case of tomato plants infected by Fusarium oxysporum, overaccumulation of ROS also results in increased lipid peroxidation [32]. Oxidative stress related cellular damage can be estimated by lipid peroxidation products, in which MDA is a great indicator. Cellular stress also occurred due to some toxins produced by pathogen that are cytotoxic to cell in rice [33] and can cause rapid lipid peroxidation and cellular damage [34]. The lower enzymatic activity of APX, CAT and POD were observed in BARI Gom 25 and BARI Gom 31, but higher in BARI Gom 33. The higher activity of those enzymes in BARI Gom 33 during pathogen infection resulted in the lower concentrations of $\mathrm{H}_{2} \mathrm{O}_{2}$, and subsequently reduced the cellular damages caused by ROS. Therefore, the difference in the activity of CAT, APX and SOD in tolerant and susceptible cultivars suggested that these enzymes played a major role for resistance in BARI Gom 33 to blast. The higher catalase activity was also observed in resistant 
lines of maize against Aspergillus flavus than susceptible one [30]; in tomato leaf against B. cincero infection resulting in reduced lesion formation [35] and their involvement against abiotic stresses was also documented [35]. Peroxidase (POX) activity is very much important in wheat cultivars against Rhizoctonia cerealis and also detrimental to resistance during late stages of infection against P. oryzae [36], is very much similar to the present study which showed higher level of POD activity in BARI Gom 33 during pathogen infection. The enzyme APX removed $\mathrm{H}_{2} \mathrm{O}_{2}$ from chloroplast, peroxisomes and mitochondria [37] and their increased activity have been well described during fungal infection [38]. In present study increased APX activity in BARI Gom 33 also suggested their role in defense mechanism. Increased of both transcript and activity of APZ was also observed in barley leaves inoculated by B. graminis [39]. The higher activity of APX, CAT and POD in BARI Gom 33 compared to BARI Gom 25 and BARI Gom 31 during pathogen infection resulted in lower accumulation of $\mathrm{H}_{2} \mathrm{O}_{2}$ and subsequently reduced MDA content restricting cellular damage caused by ROS. The result of the present study indicated the presence of a more efficient antioxidative defense mechanism in BARI Gom 33 which reduced the cellular damage by the removal of excess ROS accumulation during the infection of M. oryzae pv triticum, contributing partially resistance to blast. Further research may aimed to develop biochemical marker using antioxidant system in breeding program to select/develop blast resistant wheat variety suitable for blast prone areas in the world.

\section{CONCLUSION}

Among the sixteen cultivars of wheat tested against M. oryze pv triticum, blast severity in BARI Gom 33 is lower and the phenotypic performance of BARI Gom 33 in terms of yield and yield contributing traits is almost same or better in some extent compare to all other varieties. BARI Gom 33 exhibited an increased antioxidant enzyme activity than susceptible cultivars BARI Gom 25 and BARI Gom 31, contributed to lower concentration of reactive oxygen species (ROS) limits the cellular damage during the infection process of MoT, thus showing greater resistance to blast in wheat.

\section{ACKNOWLEDGEMENTS}

Ministry of Science and Technology, Government of the people's republic of Bangladesh for providing research grant.

\section{Author's Contribution}

GHMS Design, formulation, supervision of experiment and writing of manuscript. AH Conducting experiment, lab analysis, writing of manuscript. CSB Conducting experiments, collection and analysis of data, writing of manuscript. AM Inocula preparation, supervision.

\section{Competing Interests}

The authors have declared that no competing interests exist

\section{REFERENCES}

1. Braun HJ, Atlin G, Payne T. Multi-location testing as a tool to identify plant response to global climate change. In Reynolds CRP, editor. Climate change and crop production. London, UK CABI; 2010.

2. FAOSTAT Data, Food and agricultural commodities production. Rome, Italy 2012. http//faostat.fao.org.

3. Shewry PR, Wheat. Journal of Experimental Botany. 2009; 60 (6) 1537-1553.

4. Rosegrant MW, Agcaoili M. Global food demand, supply, and price prospects to 2010. Washington, DC 2010

5. Malaker PK, Barma NC, Tiwary TP, Collis WJ, Duveiller EP, Singh K, Joshi AK, Singh RP, Braun HJ, Peterson GL, Pedley KF. First report of wheat blast caused by Magnaporthe oryzae pathotype triticum in Bangladesh. Plant Disease. 2016; 100(11)2330.

6. Igarashi S. Update on wheat blast (Pyricularia oryzae) in Brazil. Proceedings of the International Conference-Wheat for the Nontraditional Warm Areas, CIMMYT, Mexico. 1990. 480- 483.

7. Islam MT, Croll D, Gladieux P, Soanes DM, Persoons A, Bhattacharjee P, Hossain MS, Gupta DR, Rahman MM and Mahboob MG. Emergence of wheat blast in Bangladesh was caused by a South American lineage of Magnaporthe oryzae. BMC Biology. 2016; 1484. https// doi.org/10.1186/s12915-016-0309-7

8. Farman M, Peterson G, Chen L, Starnes J, Valent B, Bachi P, Murdock L, Hershman D, Pedley K, Fernandes JM, Bavaresco J. The Lolium pathotype of Magnaporthe oryzae recovered from a single blasted wheat plant in the United States. Plant Disease. 2017 May 13; 101(5)684-92.

9. Goulart A, and Paiva F. Perdas no rendimiento de grãos de trigo causada por Pyricularia grisea, nos anos de 1991 e 1992, no Mato Grosso do Sul. Sum. Phytopathol. 2000; 26279-282.

10. Urashima AS, Bockus WW, Bowden RL, Hunger RM, Morrill WL, Murray TD, Smiley RW (eds). Compendium of wheat diseases and pests. Saint Paul, MN American Phytopathological Society.2010: pp. 22-23.

11. Arruda M A, Bueno C R N C, Zamprogno K C, Lavorenti NA, and Urashima A. Reação do trigo a Magnaporthe griseanos diferentes estádios de desenvolvimento. Fitopatol. 2005; 30121-126.

12. Cruz M F A, Prestes A M, Maciel J L N, and Scheeren P L. Resistência parcial à brusone de genótipos de trigo comum e sintético nos estádios de planta jovem e de planta adulta. Trop. Plant Pathol. 2010; 3524-31

13. Caverzan A, Casassola A, Brammer SP. Antioxidant responses of wheat plants under stress. Genetics and molecular biology. 2016 Mar; 39(1)1-6.

14. Mullineaux P M, \& Baker N R. Oxidative stress antagonistic signaling for acclimation or cell death? Plant physiology. 2010; 154(2)521-525.

15. Sharma P, Jha A B, Dubey R S, \& Pessarakli M. Reactive oxygen species, oxidative damage, and antioxidative defense mechanism in plants under stressful conditions. Journal of botany. 2012.

16. Wang ZY, Li FM, Xiong YC and Xu BC. Soil-water threshold range of chemical signals and drought tolerance was mediated by ROS homeostasis in winter wheat during progressive soil drying. J Plant Growth Regul. 2008; 27309-319.

17. Varga B, Janda T, Laszlo E and Veisz O. Influence of abiotic stresses on the antioxidant enzyme activity of cereals. Acta Physiol Plant. 2012; 34849-858.

18. Huseynova IM, Aliyeva DR and Aliyev JA. Subcellular localization and responses of superoxide dismutase isoforms in local wheat varieties subjected to continuous soil drought. Plant Physiol Biochem. 2014; 8154-60.

19. Kong L, Wang F, Si J, Feng B, Zhang B, Li S and Wang Z. Increasing in ROS levels and callose deposition in peduncle vascular bundles of wheat (Triticum aestivum L.) grown under nitrogen deficiency. J Plant Interact. 2014; 8109-116.

20. Talaat NB and Shawky BT. Modulation of the ROSscavenging system in salt-stressed wheat plants inoculated with arbuscular mycorrhizal fungi. J Plant Nutr Soil Sci. 2014; 177199-207.

21. Debona D, Rodrigues F A, Rios J A, Nascimento K J T, Silva L C. The effect of silicon on antioxidant metabolism of wheat leaves infected by Pyricularia oryzae. Plant pathology. 2014; 63(3)581-589.

22. Agrawal G K, Jwa N S, Rakwal R. A pathogen-induced novel rice (Oryza sativa L.) gene encodes a putative protein homologous to type II glutathione-S-transferases. P Sci. 2002; 1631153-1160.

23. Agrawal G K, Rakwal R, Jwa N S \& Agrawal V P. Effects of signaling molecules, protein phosphatase inhibitors and blast pathogen 
Biswas, et al.

(Magnaporthe grisea) on the mRNA level of a rice (Oryza sativa L.) phospholipid hydroperoxide glutathione peroxidase (OsPHGPX) gene in seedling leaves. Gene. 2002; 283(1-2)227-236.

24. IRRI. Standard Evaluation System for Rice. International Rice Research Institute, Los Banos, Philippines. 2014.

25. Aebi H. Catalase in vitro. In Methods in enzymology. Academic Press. 1984; 105121-126.

26. Nakano Y, Asada K. Hydrogen peroxide is scavenged by ascorbatespecific peroxidase in spinach chloroplasts. Plant Cell Physiol. 1981; 22867-880.

27. Heath RL, Packer L. Photoperoxidation in isolated chloroplasts. I-kinetics and stoichiometry of fatty acid peroxidation. Archives of Biochemistry and Biophysics. 1968; 125 189-198.

28. Velikova V, Yordancv I, Edreva A. Oxidative stress and some antioxidant systems in acid rain-treated bean plants protective role of exogenous polyamines. Plant Science. 2000; 15159-66.

29. Farhad M, Velu G, Hakim MA, Kabir MR, Alam MA, Mandal MS, Hossain A, Reza MA, Mustarin K, Jahan, AHS, Barma NCD. Development and deployment of Biofortified and blast resistant wheat variety in Bangladesh. 2018. Poster. BARI research progress. https//www.researchgate.net/publication/330073588

30. Magbanua Z V, De Moraes C M, Brooks T D, Williams W P, and Luthe D S. Is catalase activity one of the factors associated with maize resistance to Aspergillus flavus? Mol. Plant-Microbe Interact. 2007; 20697-706.

31. Rauyaree P, Choi W, Fang E, Blackmon B and Dean R. Genes expressed during early stages of rice infection with the rice blast fungus Magnaporthe grisea. Mol. Plant Pathol. 2001; 2347-354.

32. Mandal S, Mitra A, and Mallick N. Biochemical characterization of oxidative burst during interaction between Solanum lycopersicum and Fusarium oxysporum f. sp. Iycopersici. Physiol. Mol. Plant Pathol. 2008; 7256-61

33. Ou S H. Rice Diseases. Commonwealth Mycological Institute, Kew, UK. 1985.

34. $\mathrm{Fu} \mathrm{J}$, and Huang B. Involvement of antioxidants and lipid peroxidation in the adaptation of two cool-season grasses to localized drought stress. Environ. Exp. Bot. 2001; 45105-114.

35. Kuzniak E, and Sklodowska M. Fungal pathogen-induced changes in the antioxidant systems of leaf peroxisomes from infected tomato plants. Planta. 2005; 222192-200.

36. Xavier Filha M S, Rodrigues F A, Domiciano G P, Oliveira H V, Silveira $P R$ and Moreira W R. Wheat resistance to leaf blast mediated by silicon. Australas. Plant Pathol. 2011; 4028-38.

37. Quan L J, Zhang B, Shi W W and Li H Y. Hydrogen peroxide in plants a versatile molecule of the reactive oxygen species network. J. Integr. Plant Biol. 2008; 502-18.

38. El-Zahabi H M, Gullner G, and Királi Z. Effects of powdery mildew infection of barley on the ascorbate-glutathione cycle and other antioxidants in different host-pathogen interactions. Phytopathology. 1995; 851225-1230

39. Hückelhoven R, Dechert $\mathrm{C}$, Trujillo $\mathrm{M}$ and Kogel K H. Differential expression of putative cell death regulator genes in nearisogenic resistant and susceptible barley lines during interaction with the powdery mildew fungus. Plant Mol. Biol. 2001; 47739-748. 